JKAU: Med. Sci., Vol. 17 No. 1, pp: 19-28 (2010 A.D. / 1431 A.H.)

DOI: $10.4197 /$ Med. $17-1.3$

\title{
Survival and Disease Complication of Thalassemia Major: Experience of 14 Years at King Abdulaziz University Hospital, Jeddah, KSA
}

\author{
Soad Khalil Al Jaouni, MD, FRCP(C) \\ Department of Hematology, Faculty of Medicine \\ King Abdulaziz University, Jeddah, Kingdom of Saudi Arabia \\ saljaouni@kau.edu.sa
}

\begin{abstract}
Treatment of thalassemia major is complex, expensive and requires a multidisciplinary approach. Optimal clinical care is demanding and expensive, but achievable. To assess the prevalence of survival and disease complications among patients with thalassemia major treated at our center; a retrospective chart review was done of all patients followed and treated at King Abdulaziz University Hospital with a diagnosis of Thalassemia Major from 1990-2004. A total of 360 patients (203 males \& 157 females) were transfusion dependant since early childhood and treated with parenteral Deferoxamine. Out of 360 patients, 293 (90.29\%) patients were alive, 27 (7.2\%) patients had died, 15 (4.2\%) patients underwent BMT and $25(6.9 \%)$ patient' follow-up were lost. Twelve (3.3\%) patients died from heart disease. 7 (1.9\%) patients died from infections, all patients were splenectomized. The serum ferritin levels for patients who died were significantly higher than for those patients who survived (7,500 vs. 3, 200; $\mathrm{p}$ $<0.001)$. Cardiac constitutes the first important cause of death followed by infection. Complications and deaths among thalassemics is iron related organ dysfunction and age related. The majority of complicated patients were on non-optimal chelation therapy and non-compliance.
\end{abstract}

Keywords: Thalassemia major, Survival, Disease complication, University hospital, KSA

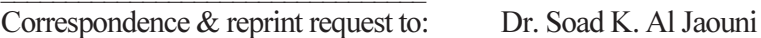

P.O. Box 80215, Jeddah 21589, Saudi Arabia
}

Accepted for publication: 14 December 2009. Received: 12 September 2009. 


\section{Introduction}

Dramatic improvements in the clinical management of thalassemia major over the last 10-20 years have led to an impressive increase in the lifespan and the improve quality of life $\mathrm{e}^{[1]}$. The prognosis of patients with transfusion dependent thalassemia major has been improved by regular transfusion and iron-chelation therapy with deferoxamine ${ }^{[2-7]}$.

This report presents the result of disease complication and causes of death in patients with thalassemia major, who were followed and treated at King Abdulaziz University Hospital (KAUH), Jeddah, Saudi Arabia over the last 14 years. Furthermore, it assesses the prevalence of survival, and their present clinical status to define the prognosis in this group of complex patients.

\section{Methods}

A retrospective chart review was done of all patients with thalassemia major followed and treated at KAUH in Jeddah, Saudi Arabia between 1990 and 2004. University Hospital, an academic tertiary care medical center, in which most of the cases followed, was referred mainly from different hospitals in Jeddah, Makkah and from different cities from the Western region of the country.

The retrospective data for this report were collected by means of specially prepared forms from hematology clinic, day care, patient cards and medical records during the time period from January 2002 through December 2004.

A total of 360 patients (203 males and 157 females) were treated and followed during the 14 years as seen in Fig. 1. The majority of these patients were homozygous $\beta$-thalassemia major and less than $2 \%$ were compound $\mathrm{HbE} \beta \mathrm{o}$ thalassemia. All were transfusion dependent since early childhood and treated with parental Deferoxamine.

The pre-transfusion hemoglobin level was maintained between 9-10 $\mathrm{g} / \mathrm{dL}$ in all the patients. Thalassemia intermedia were excluded from this analysis as well as patients with successful engraftment of transplanted stem cell.

Disease complications were assessed by measuring iron overload through assessment of iron balance, and the mean of serum ferritin 
concentration for all patients yearly. All patients were tested for Hepatitis B \& C; any seropositive patients were referred to hepatologist for follow-up and treatment.

Other complications including cardiac, endocrine, bone diseases and others were recorded from the annual referred sheet. Complicated cases were referred to different subspecialties for treatment.

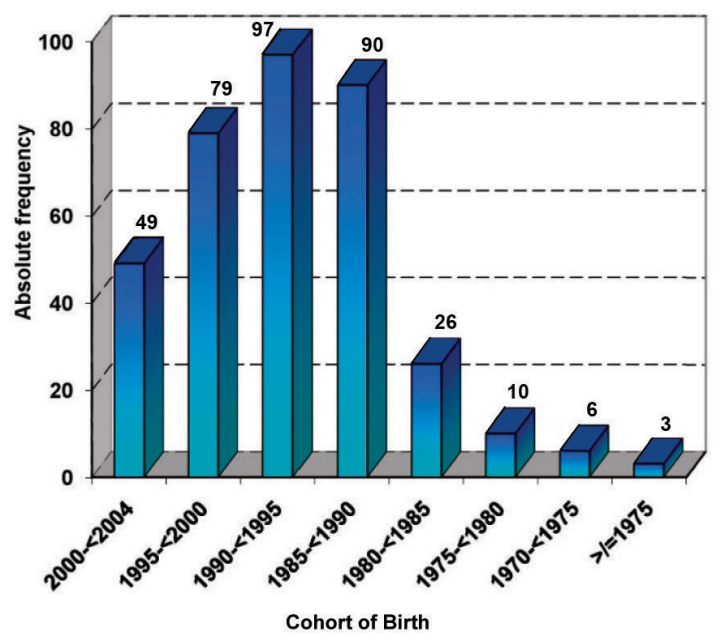

Fig. 1. Distribution of cohort by birth in all the studied thalassemia major (360 cases) at KAUH, Jeddah, KSA.

\section{Statistical Analysis}

Using SPSS program, V-10 under Windows, the descriptive statistics for continuous variables were done by calculating mean, standard deviation $( \pm \mathrm{SD})$, standard error of mean $( \pm \mathrm{SEM})$, median and range. For qualitative data, description was done by calculating numbers and percent. Analysis for quantitative data was done by "student's" $t$ test. Wilcoxon rank-sum test, $(Z)$ was performed for nonparametric analysis. Results were considered significant at $p<0.05$. Probability of survival curve as described by Kaplan-Meier method. Graphic representation was done using HGW program.

\section{Results}

Out of 360 patients (203 males and 157 females) initially enrolled in the study; the median patient age was 12.50 years (range, 1-32 years). 
The majority of patients referred to KAUH after the age of 12 years. Twenty-five $(6.9 \%)$ encountered lost follow up. Fifteen patients $(4.2 \%)$ underwent successful stem cell transplant. Twenty-five percent $(25 \%)$ of patients had undergone splenectomy at median age of 8 years (range, 2.5 -16 years).

Table 1 summarizes the patients' clinical characteristics and disease complications by age group which shows that most of the complications are age related and iron overload.

Table 1. Complication of thalassemia major by age group.

\begin{tabular}{|c|c|c|c|c|c|}
\hline & $\begin{array}{c}0-10 y \\
(n=99), \%\end{array}$ & $\begin{array}{c}11-20 y \\
(n=150), \%\end{array}$ & $\begin{array}{c}21-30 y \\
(n=26), \%\end{array}$ & $\begin{array}{c}>30 y \\
(n=3), \%\end{array}$ & $\begin{array}{c}\text { Overall } \\
(n=278), \%\end{array}$ \\
\hline $\begin{array}{l}\text { Serum ferritin }(\mathrm{ng} / \mathrm{ml}) \\
\text { Mean } \pm \mathrm{SD} \\
\text { Range } \\
\text { Median }\end{array}$ & $\begin{array}{c}2100 \pm 512.6 \\
1580-3200 \\
2115\end{array}$ & $\begin{array}{c}4920 \pm 2024.1 \\
2500-12600 \\
4850\end{array}$ & $\begin{array}{c}4104.8 \pm 1298.4 \\
3200-6000 \\
4290\end{array}$ & $\begin{array}{c}4127.3 \pm 1211.7 \\
3100-5500 \\
3900\end{array}$ & $\begin{array}{c}3272.5 \pm 1574.8 \\
1580-12600 \\
4250\end{array}$ \\
\hline Hepatitis C & $3(3.0 \%)$ & $42(28 \%)$ & $17(65.4 \%)$ & $2(66.7 \%)$ & $64(23.0 \%)$ \\
\hline Hepatitis B & $2(2.0 \%)$ & $6(4 \%)$ & $6(23.0 \%)$ & $1(33.3 \%)$ & $18(6.5 \%)$ \\
\hline $\begin{array}{l}\text { Heart disease requiring } \\
\text { treatment }\end{array}$ & 0 & $1^{*}$ & 5 & 3 & 9 \\
\hline Liver failure/cirrhosis & 0 & 0 & 1 & 1 & 2 \\
\hline $\begin{array}{l}\text { Endocrine disorders: } \\
\text {-Thyroid disease } \\
\text {-Hypoparathyroidism } \\
\text {-Diabetes Mellitus }\end{array}$ & $\begin{array}{l}0 \\
0 \\
0\end{array}$ & $\begin{array}{l}1 \\
4 \\
3\end{array}$ & $\begin{array}{l}3 \\
5 \\
8\end{array}$ & $\begin{array}{l}1 \\
2 \\
2\end{array}$ & $\begin{array}{c}5 \\
11 \\
13\end{array}$ \\
\hline
\end{tabular}

The median serum ferritin 4250 (range, 1580-12600), the median ferritin measurement had increased with age.

Of 278 patients tested for Hepatitis C viruses (HCV) $23 \%$ were seropositive, the risk increases with age $3 \%$ below age of 10 years and $66.7 \%$ with the age 30 years and above.

Organ dysfunction due to iron overload was common in adolescents and young adults; majority of complications started after 10 years of age.

No patients age 15 years or younger were reported to have heart disease requiring treatment.

Twenty-seven patients (7.2\%) died, and 251 (90.29\%) survived.

Table 2 and Fig. 2 summarize the cause of death and patients clinical characteristics. 
Table 2. Summary of the causes of death and patient clinical characteristics in 278 patients with TM treated at KAUH.

\begin{tabular}{l|c|c|c|c|c|c}
\hline \multirow{2}{*}{$\begin{array}{c}\text { Causes of } \\
\text { death }\end{array}$} & \multirow{2}{*}{$\begin{array}{c}\text { Number } \\
(\%)\end{array}$} & \multicolumn{2}{|c|}{ Age (Yrs) } & \multicolumn{3}{c}{ Serum Ferritin (ng/ml) } \\
\cline { 3 - 7 } & Mean + SD & Range & Mean \pm SD & Median & Range \\
\hline Cardiac & $12(44 \%)$ & $19.0 \pm 2.98$ & $16-24$ & $7645 \pm 3404$ & 7750 & $3000-12600$ \\
\hline Infection & $7(26 \%)$ & $14.14 \pm 2.61$ & $10-18$ & $2314 \pm 296$ & 2400 & $1800-2600$ \\
\hline Endocrine & $4(15 \%)$ & $23.0 \pm 1.83$ & $21-25$ & $6375 \pm 2206$ & 6500 & $3600-8900$ \\
\hline Liver & $1(4 \%)$ & $28.0 \pm 0$ & -- & $4000 \pm 0$ & -- & -- \\
\hline Thrombosis & $1(4 \%)$ & $17.0 \pm 0$ & -- & $3500 \pm 0$ & -- & -- \\
\hline Unknown & $2(7 \%)$ & $19.0 \pm 1.41$ & $18-20$ & $3000 \pm 707$ & 3000 & $2500-3500$ \\
\hline Total & $27(100 \%)$ & $18.59 \pm 4.21$ & $10-28$ & $5442 \pm 3346$ & 4000 & $1800-12600$ \\
\hline
\end{tabular}

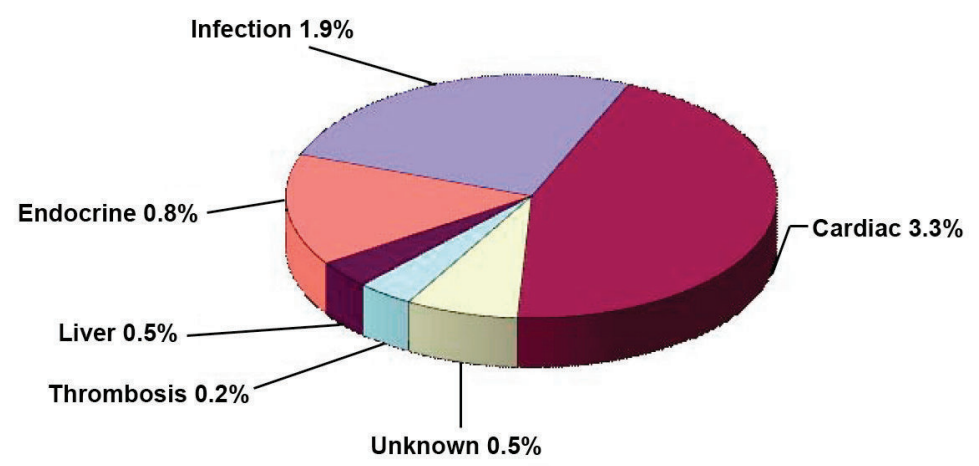

Fig. 2. The incidence of death in patients with thalassemia major between 1975-2000 treated at KAUH, Jeddah, KSA.

Twelve patients $(3.3 \%)$ died from heart disease; seven patients $(1.9 \%)$ from infections and all were splenectomized.

Three $(0.8 \%)$ died from endocrine disorders, two $(0.5 \%)$ from liver disease and two $(0.5 \%)$ had multiple organ dysfunction. One patient died from thrombosis.

On comparing, survived versus death cases regarding serum ferritin, it was found that the mean of serum ferritin in survived cases was $3009.32 \pm 1143.29$, median $=2590.0$; while in death cases they were $5442.59 \pm 3346.54$, median $=4000.0$. There was highly significant 
difference between both groups being higher in death cases with $Z=3.7$, $\mathrm{p}<0.001$.

The median serum ferritin in death cases was 4000 (range, 180012,600). However, the mean serum ferritin in cardiac cases was $7645 \pm$ 3404 , while in infection cases was $2314 \pm 296$. There was a highly significant different between both groups with $\mathrm{t}=5.39, \mathrm{p}<0.001$, being higher in cardiac cases as seen in Table 2.

Most of the complications and deaths are age related plus iron overload. The mean of age in infection cases was 14.142 .61 , while in other causes of death was $21.2 \pm 2.81$. There was highly significant difference between both groups with $\mathrm{t}=6.04$, $\mathrm{p}<0.002$, being higher in non-infected cases.

Seventy $(25 \%)$ of the studied 278 cases underwent splenectomy at median age 8 years (range 2.5-15 years). Out of them, 7 died from infection. This represents $10 \%$ of the total splenectomized cases. Thus, splenectomy is an additional risk factor.

Figure 3 shows Kaplan-Meier survival curve of patients with TM born in 1975-2000. The median age of death cases was 18 years (range, 10-28 years). It showed that $50 \%$ of death cases were at the adolescent and young adults from 16 to 22 years old. A 25\% expired below 16 years and $25 \%$ died after the age of 22 .

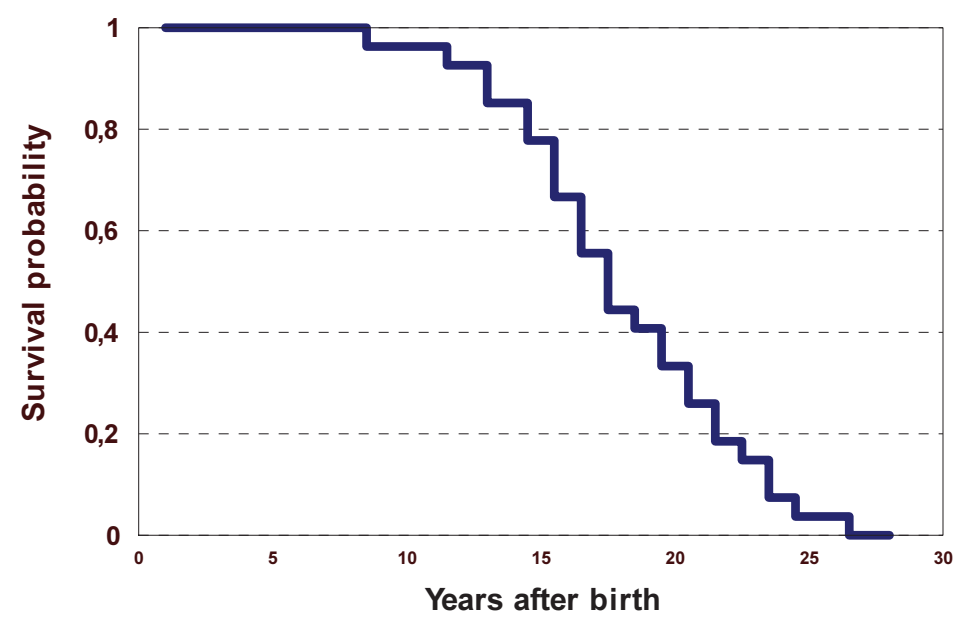

Fig. 3. Kaplan Meier survival curve in the studied 278 patients with thalassemia major treated at KAUH, Jeddah, KSA. 


\section{Discussion}

Treatment of thalassemia major is complex, expensive and requires a multidisciplinary approach. In this report it defined the current status of disease complication and the causes of death; among 278 patients were treated and followed at KAUH in Jeddah, Saudi Arabia. In spite providing a comprehensive care for this complex group of patients' deaths still occur in young patients.

Iron overload was a major cause of death among our thalassemic patients with the median serum ferritin 4,000 vs. 2,590 for patients who survive. The sixteen-year-old female patient, who died from cardiac, was having the highest level of ferritin $12,600 \mathrm{ng} / \mathrm{ml}$.

Poor compliance with parenteral chelation started at adolescent age as seen in Table 1.

A significant proportion of our patients after age of 12 years; their ferritin measurement exceeded 2,500 ng per milliliter during treatment which is a known risk factor of organ dysfunction ${ }^{[8]}$. Most of the complication among thalassemic and organ dysfunction is age-related ${ }^{[9]}$.

Cardiac constituted the first important cause of deaths in our study which is similar to previous studies ${ }^{[8,10]}$.

Proper early detection of iron overload on the heart is a crucial management in the thalassemia major. Serum ferritin is a poor indicator of myocardial iron content in early stage of iron overload ${ }^{[11]}$. Using a magnetic resonance imaging (MRI) is a reliable and safe non-invasive method for the assessment of early deposition of iron in the heart ${ }^{[12-15]}$.

Combined chelating therapy in thalassemia major improved the survival $^{[16-17]}$.

It was observed, an addition risk factor among thalassemic who had splenectomy; $10 \%$ of whom had splenectomy died from infection. The ten-year-old female patient who was admitted in septic shock and died in less than 10 hours from admission, was in prophylactic penicillin and upto-date vaccination, with the median ferritin level of $1,980 \mathrm{mg} / \mathrm{ml}$.

In spite of the complications the overall survival of our thalassemic patients is still good $293(90.29 \%)$. 


\section{Conclusion}

The prevalence of complication due to iron overload is still high. The survival of patients with thalassemia major in KAUH is good.

Preventive programs of hemoglobinopathies should be implemented as a priority in the Kingdom'.

\section{Acknowledgement}

The author would like to acknowledge all the hematologists, pediatricians and internists with different subspecialties. With special thanks for the nurses and the Saudi Society of Thalassemia, for their participation to improve the quality of life for this complex group of patients.

\section{References}

[1] Cohen A. Management of iron overload in the pediatric patient. Hematol Oncol Clin North Am 1987; 1(3): 521-544.

[2] Wolf L, Olivieri NF, Sallan D. Prevention of cardiac disease by subcutaneous deferoxamine in patients with thalassemia major. N Engl J Med 1985; 312(25): 16001603.

[3] Callea F. Iron overload and chronically transfused patients complications; numbers, scales, and clinical research. Am J Hematol 2009: 84(8): 471-472.

[4] Zurlo MG, De Stefano P, Borgna-Pignatti C, Di Palma A, Piga A, Melevendi C, Di Gregorio F, Burattini MG, Terzoli S. Survival and causes of death in thalassemia major. Lancet 1989; 2(8653): 27-30.

[5] Aldouri MA, Wonke B, Hoffbrand AV, Flynn DM, Ward SE, Agnew JE, Hilson AJ. High incidence of cardiomyopathy in beta-thalassemia patients receiving regular transfusion and iron chelation: reversal by intensified chelation. Acta Haematol 1990; 84(3): 113-117.

[6] Al Jaouni SK. Survival and disease cause of death in thalassemia major, single institute experience, Jeddah, KSA. Presented as proceeding at $11^{\text {th }}$ Congress of the European Hematology Association. Haematologica 2006: 91(S1).

[7] Ehlers KH, Giardina PJ, Lesser ML, Engle MA, Hilgartner MW. Prolonged survival in patients with beta-thalassemia major treated with deferoxamine. J Pediatr 1991; 118(4 pt 1): 540-545.

[8] Olivieri NF, Nathan DG, MacMillan JH, Wayne AS, Liu PP, McGee A, Martin M, Koren G, Cohen AR. Survival in medically treated patients with homozygous $\beta$ thalassemia. New Engl J Med 1994; 331(9): 574-578.

[9] Cunningham MJ, Macklin EA, Neufeld EJ, Cohen AR; Thalassemia Clinical Research Network. Complications of beta-thalassemia major in North America. Blood 2004; 104(1): 34-39. 
[10] Borgna-Pignatti C, Rugolotto S, De Stefano P, Piga A, Di Gregorio F, Gamberini MR, Sabato V, Melevendi C, Cappellini MD, Verlato G. Survival and disease complications in thalassemia major. Ann NY Acad Sci 1998; 850: 227-231.

[11] Al Jaouni SK. Serum ferritin is a poor indicator of myocardial iron content in early stage of iron overload in thalassemia major. Egypt J Haematol 2007; 32(3): 171-176.

[12] Anderson LJ, Holden S, Davis B, Prescott E, Charrier CC, Bunce NH, Firmin DN, Wonke B, Porter J, Walker JM, Pennell DJ. Cardiovascular T2-star (T2*) magnetic resonance for the early diagnosis of myocardial iron overload. Eur Heart $J$ 2001; 22(23): 2171-2179.

[13] Kirk P, Roughton M, Porter JB, Walker JM, Tanner MA, Patel J, Wu D, Taylor J, Westwood MA, Anderson LJ, Pennell DJ. Cardiac T2* magnetic resonance for prediction of cardiac complications in thalassemia major. Circulation 2009; 120(20): 1961-1968.

[14] Modell B, Khan M, Darlison M, Westwood MA, Ingram D, Pennell DJ. Improved survival of thalassemia major in the UK and relation to $\mathrm{T} 2 *$ cardiovascular magnetic resonance. J Cardiovasc Magn Reson 2008; 10: 42.

[15] Tanner MA, Galanello R, Dessi C, Smith GC, Westwood MA, Agus A, Roughton M, Assomull R, Nair SV, Walker JM, Pennell DJ. A randomized, placebocontrolled, double blind trial of the effect of combine therapy with deferoxamine and deferiprone on myocardial iron in thalassemia major using cardiovascular magnetic resonance. Circulation 2007; 115(14): 1876-1884.

[16] Pennell DJ, Berdoukas V, Karagiorga M, Ladis V, Piga A, Aessopos A, Gotsis ED, Tanner MA, Smith GC, Westwood MA, Wonke B, Galanello R. Randomized controlled trial of deferiprone or deferoxamine in beta-thalassemia major patients with asymptomatic myocardial siderosis. Blood 2006; 107(9): 3738-3744.

[17] Pennell DJ, Porter B, Cappellini MD, El-Beshlawy A, Chan LL, Aydinok Y, Elalfy MS, Sutcharitchan P, Li CK, Ibrahim H, Viprakasit V, Kattamis A, Smith G, Habr D, Domokos G, Roubert B, Taher A. Efficacy of deferasirox in reducing and preventing cardiac iron overload in beta-thalassemia. Blood 2010: 115(12): 2364-2371. 
در اسة شاملة لمعرفة مضاعفات مرض الثالايميا العظمى: خبرة ـ ا سنة في مستشفى جامعة الملك عبدالعزيز بجدة، المملكة العربية السعودية

$$
\begin{aligned}
& \text { سعاد خليل الجاعوني } \\
& \text { قسم أمراض الدم ، كلية الطب ، جامعة الدلك عبد العزيز }
\end{aligned}
$$

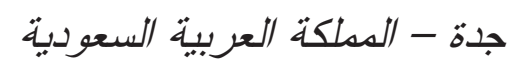

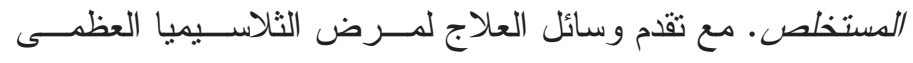

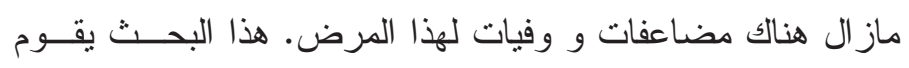

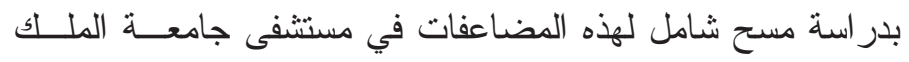

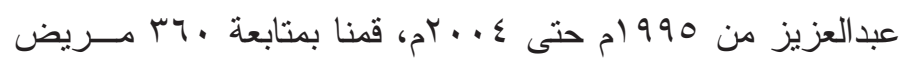

$$
\begin{aligned}
& \text { بالثلاسيميا العظمى خلال هذه الأعو ام، فوجدنا أن السبب الرئيسـي كني }
\end{aligned}
$$

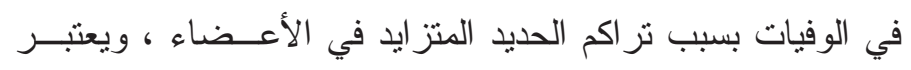

$$
\begin{aligned}
& \text { مرض القلب السبب الأول في الوفيات، فنتصح بالمتابعة المستسترة } \\
& \text { وتوفير العلاج المتكامل لهؤلاء المرضى. }
\end{aligned}
$$

